\title{
ACRL and ALA Support Academic Librarians
}

Resolutions and motions supporting librarians in the California State University and Colleges, the University of California, and the University of Chicago were adopted by the Association of College and Research Libraries and the American Library Association at their meetings in Las Vegas in June. The texts of these documents follow.

\section{California State University and Colleges}

Resolution adopted by the Board of Directors of the Association of College and Research Libraries, June 28, 1973, Las Vegas, Nevada.

WHEREAS, The American Library Association, at the request of the Association of College

\begin{tabular}{|c|}
\hline Serving libraries for over 25 years for \\
Building Programs-Reviews of Plans- \\
Equipment Layouts and Designs \\
LIBRARY MANAGEMENT and \\
BUILDING CONSULTANT, INC. \\
Box 58, Evanston, Illinois 60204 \\
Send for fre brochures \\
\hline
\end{tabular}

and Research Libraries, appointed a committee in 1969 chaired by Robert B. Downs, to investigate the situation of librarians in the California State University and Colleges (CSUC), and

WHEREAS, The Downs committee recommended that library personnel problems in the CSUC would be resolved on all major issues if all librarians in the system were granted faculty status, including, as soon as feasible, equality of salaries with other faculty, base salaries for the academic year with supplemental stipends for summer work, time and flexible schedules to facilitate study, research, and other professional activities, and the like, and

WHEREAS, The ACRL Standards for Faculty Status for College and University Librarians calls for full and meaningful faculty status, including promotion on the basis of academic proficiency and professional effectiveness, peer review, equal compensation with other faculty, academic year appointments, leaves, etc. on the same basis as other faculty, and WHEREAS, The recently promulgated Librari-

\section{Large Selection of Russian Antiquarian Material MICROFILM \\ - Literary Criticism \\ - History \\ - Social Sciences}

SPECIAL OFFER:

NEDRA - Literaturno-khudozhestvennye sborniki. Moskva, Izd. "Novaia Moskva," "Nedra," 1923-1931. V 20-ti sbornikakh.

Complete Collection in 20 Books ${ }_{\text {PRICE }} \$ 366^{00}$

Write for prices and catalog offering carefully selected lists

INTERNATIONAL MICRO-PRINT PRESERVATION, INC. 64 University Place. New York, New York 10003 
ans Personnel Plan of CSUC, while not providing for the above perquisites, adds the unusual requirement of a second master's degree or its equivalent for reclassification of librarians,

THEREFORE, BE IT RESOLVED, (1) That the ACRL Board of Directors formally communicate to the Chancellor of the CSUC system the instances in which the new personnel document fails to conform with the ACRL Standards for Faculty Status for College and University Librarians and the Downs report,

(2) That based on these differences the ACRL urge the suspension of the new personnel plan at CSUC, and

\section{New Contract Agreement at Claremont Colleges}

The Office and Professional Employees International Union, Local No. 30, AFL-CIO, CLC, representing employees of the Honnold Library of The Claremont Colleges, reached an agreement on a two-year contract with college administrators July 6, 1973, after seven months of negotiations.

"The agreement which has been reached is equitable, and speaks for itself," said Provost Howard Brooks.

Monthly minimum scales will increase from the current \$411-491 range for library assistants to a $\$ 450-500$ range. Beginning scale for librarians will decrease from $\$ 742$ to $\$ 740$ per month, although no current employees will receive a pay cut. Senior librarians will go from $\$ 777$ to $\$ 780$. Minimum student rates will increase five cents per hour each year.

Annual increases in all classifications will be $\$ 15$ per month in the second year.

Group health and life insurance and pension-retirement fund provisions are unchanged, as is the $37 \%$-hour work week. Workers become eligible for vacations earlier under the new plan, and an annual "floating" holiday has been added. Cumulative sick leave has been lengthened.

A major thrust of the contract has been to codify existing informal arrangements as to conference attendance, eligibility for professional research leaves, leaves of absence, and time off for class or lecture attendance.
(3) That the Academic Status Committee offer its assistance in revising the plan to bring it into conformity with ACRL standards.

\section{University of CaLifornia}

Resolution adopted by the Membership of the American Library Association, June 27, 1973, Las Vegas, Nevada.

WHEREAS, Academic librarians have been discriminated against as a "women's" profession in that the pay of librarians is below other nonteaching academic staff in most universities and colleges and

WHEREAS, University of California librarians are the lowest paid academic employees at the university; and

WHEREAS, The Assembly Ways and Means Committee of the California legislature has unanimously passed AB1412, introduced by the American Federation of Teachers, which would increase librarian pay by a minimum of 23 percent so as to eliminate such discriminatory practices;

THEREFORE, BE IT RESOLVED, That the American Library Association membership in Las Vegas, Nevada, June 1973,

(I) Supports all efforts to improve the pay of librarians and eliminate sex discrimination practices in the pay of librarians; and

(2) Hereby commends the California Assembly Ways and Means Committee for this historic first step toward eliminating such discrimination; and

(3) Urges the California legislature to pass AB1412, and to communicate ALA's support of AB1412 to Governor Ronald Reagan, Assembly Majority Leader Bob Moretti, Assembly Minority Leader Robert Beverly, Assemblyman John Miller, the Bill's sponsor, and to legislative leaders at appropriate times in the legislative process.

\section{Univeratix of Chicago}

Resolution adopted by the Membership of the American Library Association, June 27, 1973, Las Vegas, Nevada.

WHEREAS, Freedom of expression is guaranteed by the Constitution of the United States, and is a right of particular interest to librarians; and

WHEREAS, Librarians should be free to express controversial opinion without fear of punishment by their employers; and

WHEREAS, Many librarians at the University of Chicago have advocated the formation of a labor union for over two years; and

WHEREAS, On June 15, 1973, the positions 

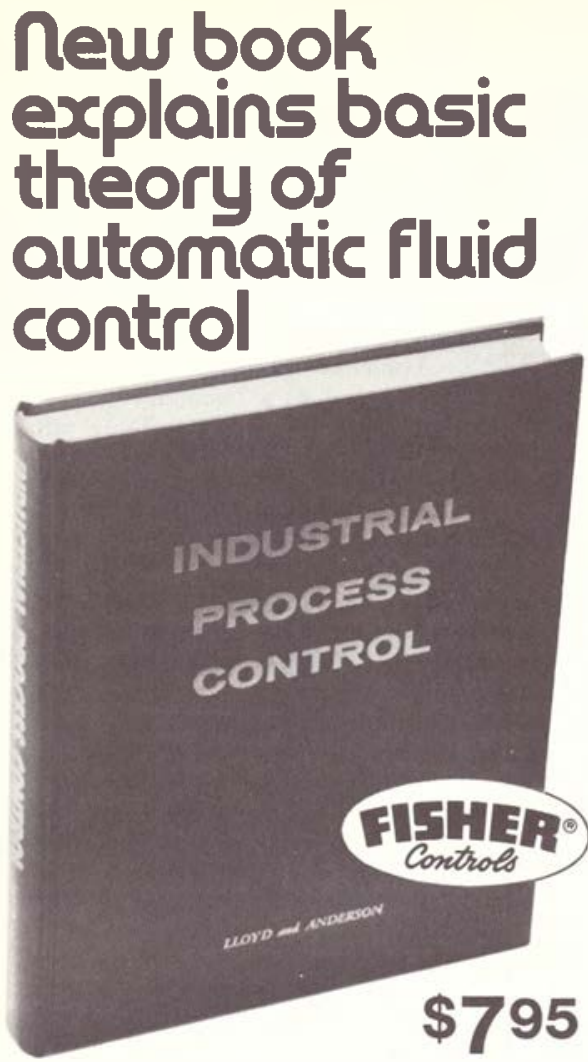

Describes application of automatic control in fluid process industries. Explores mathematical analysis of linear control systems and techniques of dealing with non-linear problems. Order today. Use coupon below.

Fisher Controls Company Marshalltown, lowa 50158

$\square$ Send "Industrial Process Control" and bill me.

$\square$ Send "Industrial Process Control." My check is enclosed.

Name

Title

Firm

Address

City

State Zip. of six professional librarians were abolished by the University of Chicago library administration on fifteen minutes notice; and

WHEREAS, Four of these positions were held by persons most active in advocating the organization of a union; and

WHEREAS, These four librarians have an aggregate seniority of thirty-two years; and

WHEREAS, Faculty and students have indicated their opposition to the action of the library administration by formation of committees, picketing in protest, and by massive refusal to use the library on June 25, 1973; and

WHEREAS, Approximately ninety percent of the library staff refrained from appearing for work on Monday, June 25, 1973, in direct protest against these actions; and

WHEREAS, The defense of intellectual freedom is a responsibility of the profession, and

WHEREAS, The actions of the administration of the University of Chicago library in this matter raise serious questions of possible violations of the intellectual freedom of the librarians involved;

THEREFORE, BE IT RESOLVED, That the membership of the American Library Association directs that a full and complete investigation of the University of Chicago library's personnel policies and procedures be undertaken immediately by the ALA Committee on Mediation, Arbitration and Inquiry, and directs this Committee to report by the Midwinter Meeting.

AND FURTHER, That the American Library Association strongly urges the University of Chicago library administration to reinstate the six discharged staff members to their positions without prejudice pending SCAMI action.

\section{University of Chicago}

Motion passed by the Board of Directors of the Association of College and Research Libraries, June 28, 1973, Las Vegas, Nevada.

That the President of ACRL communicate with the Chairman of SCMAI [ALA Staff Committee on Mediation, Arbitration and Inquiry] regarding the University of Chicago Library action and controversy and that, as a part of the SCMAI investigation mandated by the ALA membership in meeting on June 27, 1973, consideration should be given to possible violation of the ACRL Standards for Faculty Status for College and University Librarians. In addition, the good offices of the ACRL Committee on Academic Status should be offered in the resolution of this problem. 